Journal of Enterprise Information Management, 2008, Volume 21, Issue 3, Pages 227-246

This article is (c) Emerald Group Publishing and permission has been granted for this version to appear here (https://dspace.lib.cranfield.ac.uk/index.jsp). Emerald does

not grant permission for this article to be further copied/distributed or hosted elsewhere without the express permission from Emerald Group Publishing Limited. www.emeraldinsight.com

\title{
eBusiness and supply chain integration
}

\author{
Alan Smart \\ Centre for Logistics and Supply Chain Management, \\ Cranfield School of Management, Bedford, UK
}

\begin{abstract}
Purpose - The purpose of this study is to examine how four large organisations have approached the implementation of new eBusiness mechanisms: namely online order processing, eProcurement, reverse auctions, and a private exchange. The objectives are to establish whether supply chain integration is an identified goal for the firms involved and to evaluate the extent of integration achieved through these projects.

Design/methodology/approach - A case study approach is used, with four separate cases being examined, leading to cross-case analysis and conclusions. The primary form of data collection was interviews with managers participating in the implementations. In order to measure the degree of supply chain integration pertaining in the examples, two frameworks from the literature are used.

Findings - In three of the cases it is established that there is very little, or nil integration at supply chain level and only in one case is there evidence of a supply chain perspective contributing to the project. Three of the firms did not consider the supply chain implications of implementing their eBusiness applications.

Research limitations/implications - The article builds on previous studies and illustrates the problems of achieving integration in the supply chain. Further research is needed to establish common attributes relating to supply chain integration.
\end{abstract}


Practical implications - Three of the projects examined here were based predominantly on a business case for the implementing firm only. Firms need to be aware that IT projects by their trading partners may have supply chain cost implications for their own business.

Originality/value - Whilst much of the literature propounds the need for integration, leading to extension of the supply chain concept, firms are pursuing IT implementations which are premised solely on internal benefits. The research illustrates that, if the new eBusiness mechanisms are to support wider supply chain goals, then the focal firms involved must take a more holistic view of how and why such solutions are implemented.

Keywords: Communication technologies, Electronic commerce, Integration, Supply chain management

\section{Introduction}

Interest in supply chain management has grown significantly since its inception in the 1980s. During this time it has been transformed from a primarily operational activity focusing in the early years on distribution or on supporting the firm's manufacturing objectives and is now recognised as a strategic concept which spans functions and crosses inter-organisational boundaries. Professionals involved in managing supply chains today make interventions in an increasingly extended range of activities in the value chain both upstream, facing towards suppliers and downstream, facing towards customers. Over time, the supply chain has become a key factor in achieving both cost and service improvements and has assumed a more central role in the business planning of successful organisations. In the personal computer industry for example, Dell Corporation engineered its supply chain using make-to-order, outsourced logistics, low inventories and direct distribution in order to achieve significant competitive advantage over its rivals (Christopher, 2005).

Companies seeking to leverage the supply chain as a means to improved performance have increased the emphasis on developing closer relationships with suppliers, distributors or customers and there has been a consequent movement towards longer-term relational policies and a growth in partnering. This approach is 
based on the premise that a co-operative philosophy leading to more integration of processes and systems with firms in the supply chain creates greater network-wide efficiencies (Lambert and Cooper, 2000; Hammer, 2001). In an increasingly complex world of globalised trade with extended lead times and greater risk, this integration in the supply chain will require supporting information systems and technology. The growth of the internet and technologies which enable real-time information sharing such as inter-connected ERP systems, web-based EDI, electronic portals and online order processing systems, can potentially support the building of closer links with customers, suppliers and third-party vendors such as logistics service providers. In practice however, the progress towards such supply chain integration between firms has often been stalled by factors such as rival cultures, information technology deficiencies, lack of process alignment and other organisational legacies (Barratt and Oliveira 2001; Akkermans et al., 1999). Hence whilst this new technology offers much promise, examples of its success in transforming supply chain practice are still relatively few in number. A growth in case evidence on supply chain-related eBusiness projects will help our understanding of success or failure in achieving such 'integration'.

In this article we examine four organisations who have implemented eBusiness solutions at different points in the supply chain. The four examples illustrate how these recently-emerged mechanisms are being adopted in varying organisational situations. The case firms are compared and contrasted to determine how such technologies are being used in different functional areas which make up the supply chain. The article has two research aims:

Firstly: to identify the business drivers for the eBusiness implementation undertaken by these firms;

Secondly: to define the level of supply chain integration achieved in each of the cases examined, using integration frameworks from the literature as a point of reference. 


\section{Supply chain management and Integration}

The concept of supply chain management (SCM) developed out of the growth in importance of logistics planning across a range of industries. Initial improvements were at the level of the individual firm, with a focus on breaking down internal functional and management silos. The model proposed by Stevens (1989) outlined an approach to achieving supply chain integration, based on a progression from this silo-based activity to interdependent functions between suppliers, OEMs and customers within the supply chain. As firms sought to further improve their operational performance it became necessary to seek inter-organisational answers to logistics problems. Solutions with an external focus began to appear, characterised by the sharing of resources, utilising third parties and deeper reliance on bought-in expertise. This led to specific developments such as outsourcing, growth in commonuser assets and vendor managed inventory (Venkatesan, 1992; Dong and Xu, 2002; Knemeyer and Murphy, 2005).

Moving further, firms began to experiment with the potential benefits of wider cooperation with both suppliers and customers at different stages in the supply chain. On the supply side, the lean school advanced the concept of closer supplier collaboration as leading to cost reduction and greater efficiency (Womack and Jones, 1996); alongside this, a raft of literature has emerged outlining the benefits to be achieved in closer alignment of supply with the core activities of the firm and the move away from traditional arms-length or adversarial relationships (Spekman et al., 1994; Goffin at al., 1997; Hines 1996; Ellram and Hendrick, 1995). On the demand side, within retail in particular, customer-facing initiatives such as Quick Response logistics (Christopher and Juettner, 1999) and Collaborative Planning, Forecasting and Replenishment (Steerman, 2003) have been advanced to decrease lead-times, reduce inventory levels and improve responsiveness to variations in demand. The theme of much of this development has been on the notion of integration of activities and processes between members of the supply chain, where a major facilitator is the reciprocity of information (Croxton et al., 2001; McAdam and McCormack, 2001). For example, the exchange of electronic point of sale data between food retailers and their suppliers to manage order scheduling has enabled improved fulfilment accuracy and on-shelf availability (Christopher, 2005). 
When positing support for stronger external integration, it has been suggested that the benefits increase as the level of supply chain integration grows, both upstream (Tan et al., 1998; Krause, 1999; Narasimhan and Das, 1999) and downstream (Reeder and Rowell, 2001; Gilbert and Ballou, 1999; Croxton et al., 2001). Indeed, talk of integration is now commonplace in the literature and it is frequently taken as a standard requirement of successful management of the supply chain, that integration will take place (Stank et al., 1999; Frohlich and Westbrook, 2001). Evidence has further been proffered that the use of eBusiness tools leads to a greater degree of integration within the supply chain (Cagliano et al., 2003). This debate takes place against a background notion that greater co-operation between trading partners is necessary for successful management of the supply chain, with all parties to the transaction potentially benefiting from the efficiencies achieved (Bowersox et al., 2003).

Despite the theories advancing closer working and some documented cases of success, in most industries it has proved extremely difficult to achieve genuine integration between firms operating in the chain. Fawcett and Magnan (2002) have illustrated that even in the US market where supply chain techniques are more widely understood, the extent of integration between firms is limited. Equally, Akkermans et al. (1999) demonstrated that functional thinking is predominantly the norm and that the arrival of new technology will not alter the situation, without significant organisational and cultural change. This position is supported by evidence from a survey by Bagchi and Skjoett-Larsen (2002) who reveal the problems of achieving IT and SCM integration between organisations. One of the concerns faced by functional managers within different firms in the supply chain is 'yielding sovereignty' (Fawcett and Magnan, 2002) and the fear of loss of control. Other barriers to integration include technology itself, organisational focus, trust, people and internal structure (Barratt and Oliveira, 2001; Frohlich, 2002; Jharkharia and Shankar, 2005). Hence whilst commentators have advanced the need for and potential benefits of integration, evidence of its success and how to achieve it has been less common.

The discussion of integration and how to measure it is hindered by the lack of a standard or widely-adopted definition of its meaning. This conundrum could prove a valuable area for further research, which might assist both academics and practitioners in their assessment of integration success. However, three articles in 
particular offer useful descriptions and frameworks for evaluation purposes. Firstly, Fawcett and Magnan (2002) propose four 'primary types of integration' (p. 344). These are:

1) internal, cross-functional process integration,

2) backward integration with valued first-tier suppliers, leading to integration with second-tier,

3) forward integration with valued first-tier customers,

4) complete forward and backward integration.

Secondly, in a detailed review of the meaning of supply chain integration, Bagchi and Skjoett-Larsen (2002) suggest two modes for categorisation in this domain, namely Information Integration and Organizational Integration. They outline the processes and characteristics which define these two modes and propose three 'stages of integration' within each mode, which are low, medium or high. In a third example, Frohlich and Westbrook (2001) offer a definition based on the concept of 'arcs of integration'. They define five 'mutually exclusive groups' representing the integration strategies of the firms analysed in the study, using quartiles to allocate respondent firms into appropriate groups. These five arcs are:

1) inward-facing,

2) periphery-facing,

3) supplier-facing,

4) customer-facing, and

5) outward-facing.

Further comment on the applicability of these frameworks to our case studies is offered in the following section. 


\section{Research methods}

Whilst the body of literature on supply chain management continues to grow, there is little empirical evidence demonstrating how, where and why supply chain integration has been achieved through eBusiness implementations. Moreover, much of the material referenced in early papers on eBusiness came from consultancy or software firms, whose purpose was often to promote these mechanisms, rather than offer empirical support of their success or failure.

This was an exploratory study of newly-emerged phenomena and reflecting the two research aims of the article listed above, the purpose of the project was to define the degree of integration in a variety of supply chains where e-Business solutions had been implemented. In order to address the practical issues at stake, we selected a case study research design. Case studies can be a valuable method when investigating contemporary phenomena in their real, industrial and commercial context, as 'the case study allows an investigation to retain the holistic and meaningful characteristics or real-life events' (Yin, 1994: 3). We adopted the theoretical sampling approach outlined by Eisenhardt (1989) in developing our case study examples. Four companies were selected as examples of implementation of one of the eBusiness mechanisms (see Table 1). A single case would not have captured the variety of the eBusiness mechanisms being used within organisations, hence a firm was selected to provide a basis for analysis of each of the four mechanisms. Three of the firms listed in Table 1 preferred not to be identified by name.

Table 1: Case study organisations \& focus of research

\begin{tabular}{|l|l|}
\hline \multicolumn{1}{|c|}{ Organisation } & \multicolumn{1}{c|}{ eBusiness solution } \\
\hline Firm A & $\begin{array}{l}\text { Sales order processing through online catalogue - sell- } \\
\text { side }\end{array}$ \\
\hline Firm B & $\begin{array}{l}\text { eProcurement system for automated purchasing - buy- } \\
\text { side }\end{array}$ \\
\hline Firm C & Online reverse auctions - buy-side \\
\hline Cisco Corporation & $\begin{array}{l}\text { Supply chain co-ordination through virtual network } \\
\text { 'ecosytem' - private exchange }\end{array}$ \\
\hline
\end{tabular}


The principal method of data collection was through interviews with senior managers in the selected organisations. Those managers were located in Supply Chain/Logistics, Purchasing, Marketing and IT functions. In all cases, more than one interview took place in each company in order to avoid bias in responses based on the respondents' functional responsibility. Information on respondents is shown in Table 2.

Table 2: Interviewees from the case study organisations

\begin{tabular}{|l|l|}
\hline \multicolumn{1}{|c|}{ Case company } & \multicolumn{1}{c|}{ Interviewees } \\
\hline Firm A & $\begin{array}{l}\text { Logistics Manager } \\
\text { eBusiness Manager } \\
\text { Marketing Director }\end{array}$ \\
\hline Firm B & $\begin{array}{l}\text { Purchasing Director } \\
\text { Regional Logistics Manager } \\
\text { IS Manager }\end{array}$ \\
\hline Firm C & $\begin{array}{l}\text { Procurement Manager } \\
\text { Category Manager } \\
\text { Supply Chain Manager }\end{array}$ \\
\hline Cisco Corporation & $\begin{array}{l}\text { Regional Supply Chain Manager } \\
\text { Purchasing Manager } \\
\text { IT Integration Manager }\end{array}$ \\
\hline
\end{tabular}

The framework for the interviews was based on a number of key subject areas such as: drivers behind eBusiness adoption; successes and failures in the projects; how a business case was created; the levels of integration targeted and achieved (the framework for interviews in shown in Appendix A). Respondents did in some situations reply only on questions where they were able to contribute, according to their roles or responsibilities. The subject areas were chosen to support the research aims established for the project and were informed by issues explored in notable earlier studies such as Bagchi and Skjoett-Larsen (2002), Frohlich and Westbrook (2001) and Akkermans et al. (1999). The interviews were structured on themes to ensure coherence and continuity between interviews conducted at different times and locations. To allow further verification of information provided at interviews, data 
were obtained from the firms on some key metrics such as customers or suppliers using the technology, numbers of orders processed, estimated or measured savings achieved. Additionally, access was granted in some cases to allow direct observation of activities within the business, or with suppliers/customers as appropriate to the case. Figure 1 shows the process followed in this research project.

Figure 1: Flowchart of research method

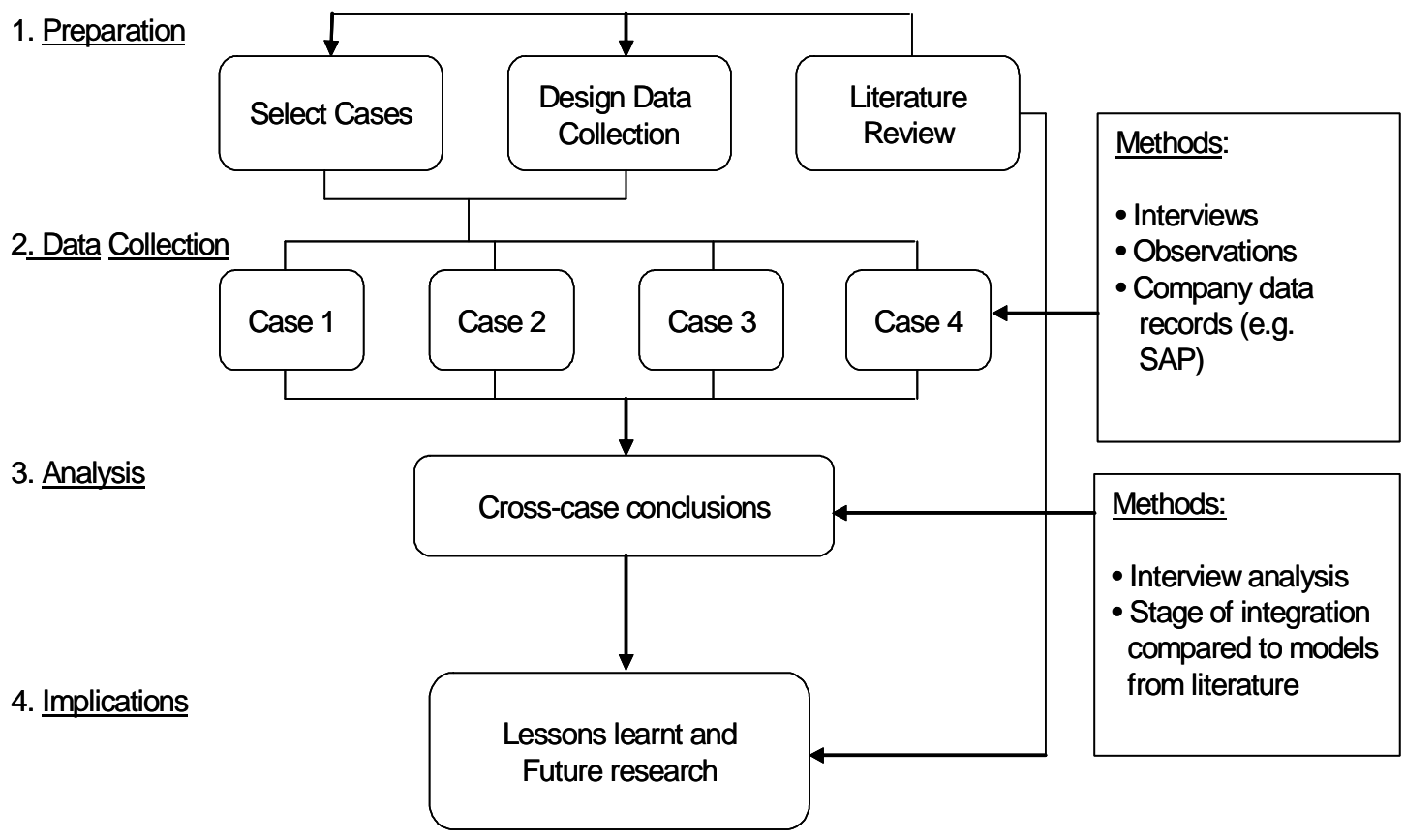

In each case there is a focal firm, leading the eBusiness initiative, targeting either its suppliers, customers or both. The research takes this focal firm as the initial unit of analysis and examines the integration impact on trading partners affected by the eBusiness initiative. The results from the data collection process are written up as individual cases, following which the paper offers a discussion of the issues raised during the study, though cross-case analysis and comparison, in order to draw further conclusions on the type of supply chain integration. To develop this discussion a framework was required and we adopted two examples from the literature as a basis for comparison in the case studies. Firstly the 'Arcs of integration' model developed by Frohlich and Westbrook (2001), shown in Figure 2 and secondly the 'Stages of integration' framework (Bagchi and Skjoett-Larsen, 2002), shown in Figure 3. These models allow a typological description of the integration achieved in each company case, although they do not automatically 
assist the discussion of specific operational linkages, which naturally vary according to the practices in place between individual firms. This point is addressed further in the concluding section of the paper.

Figure 2: Arcs of integration

To what extent do you organizationally integrate activities with your customers and suppliers?

1. Inward-facing

Classified as inward-facing if response was

a. In lower quartile for suppliers, and

b. In lower quartile for customer

2. Periphery-facing

Classified as periphery-facing if response was:

a. Above lower quartile for suppliers or customers, but

b. Below upper quartile for suppliers and customers

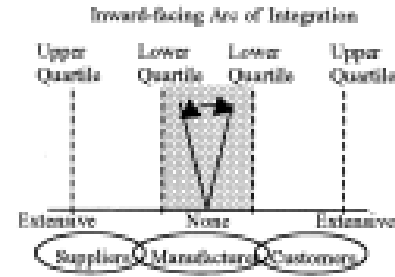

Periphary fazine Are of latigswion

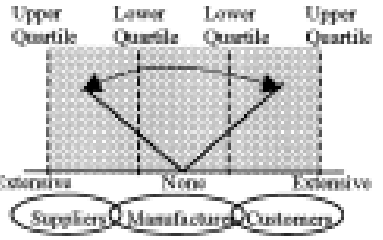

Seppliet-facine ane of Iriegntion

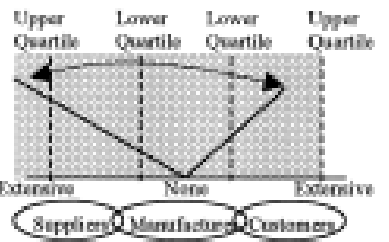

3. Supplier-facing

Classified as supplier-facing if response was:

a. In upper quartile for suppliers, and

b. Below upper quartile for customers

4. Customer-facing

Classified as customer-facing if response was:

a. In upper quartile for customers, and

b. Below upper quartile for suppliers

\section{Outward-facing}

Classified as outward-facing if response was:

a. In upper quartile for suppliers, and

b. In upper quartile for customers

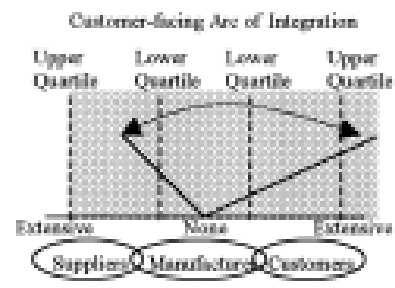

Ontward-ficing Aee of Irtegetien

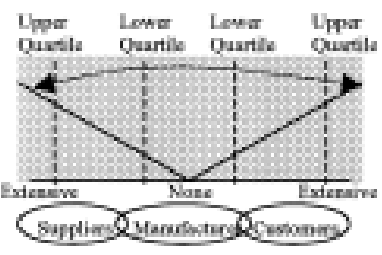

Fig. 3. Cperationdizwion of afes of integation.

(Source: Frohlich M. and Westbrook, R. (2001) 
Figure 3: Stages of Information and Organizational Integration

\begin{tabular}{|c|c|c|c|}
\hline \multicolumn{4}{|c|}{$\begin{array}{c}\text { Table } 4 \\
\text { Stages of Information Integration }\end{array}$} \\
\hline $\begin{array}{l}\text { Supply Chain } \\
\text { Integration Using }\end{array}$ & LOW Integration & MEDIUM Integration & HGH Integration \\
\hline Transaction Systems & $\begin{array}{l}\text { MRP II Systems } \\
\text { Legacy Systems }\end{array}$ & $\begin{array}{l}\text { ERP Systerns } \\
\text { - Intra-company } \\
\text { - Rigid interfaces } \\
\text { Value: Mechanization of } \\
\text { existing processes }\end{array}$ & $\begin{array}{l}\text { ERP and Supply Chain Planning } \\
\text { (SCP) systems } \\
\text { - Inter-company integration } \\
\text { - Fiexible interfaces } \\
\text { Value: Process Improvement }\end{array}$ \\
\hline $\begin{array}{l}\text { Communication } \\
\text { Systems, } \\
\text { fnternet/Extranet }\end{array}$ & $\begin{array}{l}\text { E-mail/Fax/phone } \\
\text { Internet/Extranet only } \\
\text { used for fimited purposes }\end{array}$ & $\begin{array}{l}\text { Few EDI/Internet links to } \\
\text { Customers/suppliers } \\
\text { Extranet }\end{array}$ & $\begin{array}{l}\text { Extensive use of EDI//nternet/XML } \\
\text { links within supply chain }\end{array}$ \\
\hline $\begin{array}{l}\text { Bar-coding and Track- } \\
\text { and-trace Systems, } \\
\text { Electronic POS } \\
\text { (point-of-safe) } \\
\text { Data Capture, } \\
\text { Inventory Visibility }\end{array}$ & $\begin{array}{l}\text { Only bar-coding of } \\
\text { finished products } \\
\text { Track-and-trace } \\
\text { and Electronic } \\
\text { POS not used }\end{array}$ & $\begin{array}{l}\text { More extensive bar-coding. } \\
\text { automated e-mail updates } \\
\text { and confirmations }\end{array}$ & $\begin{array}{l}\text { Bar-coding from entry to dispatch } \\
\text { Track-and-trace throughout the SC } \\
\text { Key suppliers and } \\
\text { custorners connected }\end{array}$ \\
\hline $\begin{array}{l}\text { Vendor Managed } \\
\text { Inventory (VMI) } \\
\text { Collaborate Planning, } \\
\text { Forecastlng and } \\
\text { Replenishment (CPFR). } \\
\text { Customer Relationship } \\
\text { Management (CRM) }\end{array}$ & Not used & $\begin{array}{l}\text { Experimental stage with } \\
\text { one or a few suppliers/customers }\end{array}$ & $\begin{array}{l}\text { Strategic suppliers have access to } \\
\text { production plans, materials } \\
\text { requirements, sales forecasts } \\
\text { and orders } \\
\text { CPFRNMI with key } \\
\text { suppliers/customers } \\
\text { CRM with key customers }\end{array}$ \\
\hline
\end{tabular}

\begin{tabular}{|c|c|c|c|}
\hline \multicolumn{4}{|c|}{$\begin{array}{c}\text { Table } 5 \\
\text { Stages of Organizational Integration }\end{array}$} \\
\hline $\begin{array}{l}\text { Organization } \\
\text { Characteristics }\end{array}$ & LOW integration & MEDIUM Integration & HIGH Integration \\
\hline $\begin{array}{l}\text { Status of Logistics/SCM } \\
\text { in the Organization }\end{array}$ & $\begin{array}{l}\text { Logistics sub-function } \\
\text { Not part of senior } \\
\text { management team }\end{array}$ & $\begin{array}{l}\text { Unified logistics function } \\
\text { under one organizational entity }\end{array}$ & $\begin{array}{l}\text { Logistics/SCM member of } \\
\text { corporate management group }\end{array}$ \\
\hline Degree of Integration & $\begin{array}{l}\text { Fragmented logistics } \\
\text { activities }\end{array}$ & $\begin{array}{l}\text { Internal integration across } \\
\text { functions }\end{array}$ & $\begin{array}{l}\text { Integrated across } \\
\text { supply chain/process oriented }\end{array}$ \\
\hline Importance of Logistics & $\begin{array}{l}\text { Logistics not considered } \\
\text { a core competence }\end{array}$ & $\begin{array}{l}\text { Logistics considered a } \\
\text { critical activity }\end{array}$ & $\begin{array}{l}\text { Logistics/SCM considered } \\
\text { a core competence }\end{array}$ \\
\hline $\begin{array}{l}\text { Communication Across } \\
\text { the Supply Chain }\end{array}$ & $\begin{array}{l}\text { Few contact points } \\
\text { between companies in the } \\
\text { supply chain }\end{array}$ & $\begin{array}{l}\text { Regular contact at top/senior } \\
\text { levels-rare operational } \\
\text { level contact }\end{array}$ & $\begin{array}{l}\text { Multiple contact points } \\
\text { at all management levels }\end{array}$ \\
\hline Governance Structure & $\begin{array}{l}\text { Arm's length relationship- } \\
\text { market-based }\end{array}$ & $\begin{array}{l}\text { Partnership only at sefected } \\
\text { areas and levels-hybrid } \\
\text { organization (semi-strong form) }\end{array}$ & $\begin{array}{l}\text { Virtual integration-hybrid } \\
\text { organization (strong form) }\end{array}$ \\
\hline Formal Lateral Organizations & No cross-functional teams & $\begin{array}{l}\text { Cross-functional teams } \\
\text { in some areas } \\
\text { Key account managers }\end{array}$ & $\begin{array}{l}\text { Teams across the supply chain- } \\
\text { reguiar interaction }\end{array}$ \\
\hline Periormance Measurement & $\begin{array}{l}\text { Measurement of delivery } \\
\text { service and inventory } \\
\text { levels in some parts of the } \\
\text { supply chain }\end{array}$ & $\begin{array}{l}\text { Measurement of order lead time, } \\
\text { logistics costs and service levels } \\
\text { Joint measurement in } \\
\text { some interfaces }\end{array}$ & $\begin{array}{l}\text { Measurement of performance } \\
\text { of supply chain processes } \\
\text { Performance data shared across } \\
\text { the supply chain } \\
\text { Focus on end-customer value }\end{array}$ \\
\hline
\end{tabular}

(Source: Bagchi, P., \& Skjoett-Larsen, T. (2002). 


\section{Case studies}

\subsection{Company A: sales order processing (SOP)}

Company A is a business-to-business (B2B) distributor of spares, accessories, electronics and industrial/commercial equipment serving both the business and private user, primarily in European markets. The company stocks 130,000 supplier products and fulfils a new order every ten seconds. Its model is one of high service levels and high prices - orders are taken on day one for domestic delivery on day two through its internally owned and managed distribution network. A traditional catalogue sales approach was used up to the 1990s when the company began experimenting with new electronic channels and was the first in the UK to offer a business to business catalogue on CD ROM. The company regarded the Internet as an obvious extension to its marketing channels and in 1998 launched an interactive web site.

Their web-based business is an illustration of the B2B sell-side model, with its focus on moving customers online. Sell-side mechanisms are managed by the supplier firm, using the web as a sales and order processing tool. The interactive sales order processing software allows the firm to capture order data which is connected into its internal IT structure such as an ERP system, to enable order processing, invoicing and settlement. The sell-side model has a further strategic dimension however as it is seen as an alternative to and defence against, the implementation of buy-side (eProcurement) systems, used by an increasing number of buying firms. As seen in the Company B case below, internally deployed buying systems can be a powerful method for taking control of purchases to achieve buying leverage. Company $A$ recognised early in the eBusiness cycle that this trend was a threat to its business model, which was based on higher prices through a service commitment. Buy-side mechanisms including online auctions have the potential to commoditise products, allowing the buyer greater power over suppliers and to exercise purchasing leverage.

The company has targeted a specific market segment with its sell-side offer, being SMEs or larger companies who wish to better manage the 'tail' of their purchases. For a buyer, a purchase order can cost up to $\$ 150$ to process, hence a reduced cost for low value items is attractive for small buyers. Using pareto analysis, it established that many firms have a large percentage of $C$ class purchases where the cost of ordering is significant in relation to order value. Customer profiling reveals 
that a typical customer purchasing only one product buys it twenty times per year, whereas a customer purchasing 3500 products usually buys each only once or twice. Hence it aims to serve the segment where process savings are more significant than purchase savings. To facilitate customer adoption further, the firm offers its own hosted buy-side application called Purchasing Manager (PM), which it offers free of charge for regular customers on the basis that they will increase their purchasing volumes. PM offers similar functionality to buy-side tools offered by software vendors such as Ariba, with facilities for purchase order approval, workflow management, spend analysis/reporting and job costing. This tool helps circumvent the need for individually tailored integrations of competing buy-side software with customers.

So where are the supply chain benefits in this model? Customers achieve some savings in process costs through automated online buying and can offer a standard, streamlined solution to users within their organisations. Company A achieves some sell-side process integration by taking customer order data direct into its financial and operating systems. However the customer cannot integrate to operations at its end as the system does not facilitate capture of data from the ordering system back into the customers' ERP or legacy systems. Equally, PM cannot be used on web sites offered by its competitors. This case illustrates the advantage of a sell-side model for suppliers where a firm with a powerful supply chain positioning or service proposition can gain control of the sales channel to substantially reduce its cost of sales. Supply chain benefits in this model are limited and effectively accrue to the supplier, which is able to automate its information flow. However, wider processes are not coordinated with customers and supply chain integration effectively ceases at the customer's purchasing department. Here, the key resource is operated by Company A, which has deployed the sell-side mechanism to achieve greater channel dominance. Our conclusion in this case example is that supply chain integration was neither a driver for adoption of this technology, nor an outcome of its implementation.

\subsection{Company B: procurement process reengineering}

As the telecoms sector grew rapidly though the 1990s, emphasis was primarily on market share, product introduction and developing global capabilities. Company $B$ was typical of this growth but by 2000 it saw profits declining and the threat of increased competition. Costs became an important issue and the firm decided to 
exploit the new eProcurement technologies available. After an initial pilot to prove the business case, a project was designed to implement a business-wide automated procurement system. The focus of this case is the firm's buy-side application which automates the 'requisition-to-payment' cycle and utilises electronic catalogues and purchase orders, with transactional activities being devolved away from the Procurement function towards users in the business.

The changes achieved in procurement practice are summarised in Table 3. In order to audit the benefits achieved, the firm engaged external parties such as research firm Gartner to confirm the savings delivered, which helped in their business case to the organisation.

Table 3: Company B eProcurement project - before and after

\begin{tabular}{|l|l|}
\hline \multicolumn{1}{|c|}{ Before } & \multicolumn{1}{c|}{ After } \\
\hline Disconnected and duplicate systems & One global purchasing system \\
\hline No requisition to pay process & One global requisition to pay process \\
\hline Maverick buying the norm & Spend directed to chosen vendors \\
\hline No visibility of spend and supplier data & Total spend and supplier data visibility \\
\hline Approval system open to abuse & Compliance and control \\
\hline Waste and inefficiency & Efficient system with 'hard' savings \\
\hline
\end{tabular}

The benefits for the company however were not limited to those illustrated. More robust spend analysis tools led to improved buying leverage, contract compliance and price reductions, but most importantly the role of the central procurement personnel changed from tactical to strategic activities, with the headcount reducing from over one hundred to around fifty.

Buy-side procurement applications provide well-documented benefits for the implementing firm (Croom, 2000; Puschmann and Alt, 2005) but an issue of concern has been whether suppliers see any benefits in such projects or are merely required to increase their transactional cost to pay for such systems in their customers. The company recognised this problem and to speed and facilitate adoption, paid for their suppliers' catalogue and data transfer costs for the first year of the project. Several routes were used to enable inter-connectivity of ordering systems with suppliers: hosted electronic catalogues, third party marketplaces, connections to sell-side sites 
and in one case, direct connectivity between compatible SAP systems. This degree of systems connectivity goes beyond what most firms have managed to achieve. However, despite Company B's focus on supplier enablement, the emphasis here is not on the supply chain, but a narrowly prescribed procurement cycle. Moreover, all the measures and benefit calculations are based on standard purchasing KPIs, with effectively no analysis of benefits the project might provide at supply chain level. The project was clearly defined to provide benefits to Company B - the Board of Directors was unlikely to approve any IT implementation which did not rigorously support that. Any benefits accruing to suppliers and third parties in the project were incidental to that case.

Commentators have included buy-side applications in taxonomies of integration tools and it is evident from this case that some data and process integration took place, with automation becoming the norm in purchasing transactions. It is misleading however to suggest that buy-side tools are producing greater levels of supply chain integration. The integration which does take place is solely within the requisition to payment cycle and involves the supplier's sales order, buyer's purchase order and buyer's accounts payable. This is a very meagre step towards supply chain functional integration. More importantly perhaps, the key benefit of buy-side eProcurement for the firm comes not from the process improvement, but from the increased buying leverage created through spend visibility and contract compliance. The primary focus of such projects is creating value for the buying firm through purchasing leverage. Functions beyond procurement may never become involved in any greater extent of data sharing than before and integration benefits at the supply chain level may be limited or non-existent in such cases.

\subsection{Company C: Online reverse auctions (ORAs)}

Due to recessionary conditions in the airline industry Company $\mathrm{C}$, like many of its competitors, embarked on a business-wide cost reduction programme, with specific targets being established for operating units. The procurement function was central to this programme and adopted the newly emerging eProcurement technologies as a means to pursue cost savings. Online reverse auctions (Smart and Harrison, 2003) were one of the solutions adopted, alongside buy-side software. Initially the firm experimented with reverse auctions in a number of product and service categories and following successful outcomes, extended the mechanism into additional areas of 
direct spend. The key benefits achieved with ORAs were price visibility and process cost improvement. Process cost improvement came from the ability to tender more frequently; contraction of purchase cycle time; faster award of contracts; reduced paper and manual effort; lower transaction costs and improved Procurement functional productivity. These process benefits all attribute to the buying firm, although some suppliers involved identified potential benefits for themselves under similar headings. However, the objective of the ORAs for the buyer was specifically purchase cost reduction, which formed the basis of targeting and measurement for the Procurement functional managers.

In this case study, the suppliers involved in the auctions who were interviewed gave their responses to the implementation of ORAs and their views were mixed. Whilst many recognised potential benefits for themselves and the opening up of a lower cost sales channel, several expressed doubts about the longer term effect, through more regular changes in supply, ongoing pressure on price and a shorter-term focus to the relationship. The critical observation is that many suppliers saw this mechanism as working against broader supply chain principles such as collaboration and process or system integration. Some suggested they would be unwilling to invest in IT resources and information sharing with suppliers where there was a constant threat of substitutes offering marginal price advantages. The response of the buyer here is crucial - where the relationship issues are handled sensitively it will be possible to continue to engage suppliers in debates about integration, information sharing and process improvement, for joint gain. In the case of Company $C$ the agenda was more fundamental, with cost management taking precedence over supply chain criteria.

This situation raises the concern that auctions are not a genuinely supply chain supportive mechanism as they reduce the focus on integration and adoption of operational improvement tools, instead driving cost improvement at the expense of a firm's supply chain partners (Emiliani, 2000). Faced with this question, procurement managers at the focal firm were ambivalent. Those with responsibility for MRO category products were usually unconcerned with the broader supply chain, quoting the need for survival in the tight market conditions as a basis for ORA adoption. Category managers in direct products had more concern for the impact on relationships with the supply base, but were still inevitably driven by the costreduction agenda. Hence in this case, reverse auctions were perceived by buyers 
primarily as a mechanism for market price disclosure, with process improvement being a secondary issue. Indeed the process aspect was not seen by any of the managers interviewed as an issue at supply chain level: process improvement was an internal benefit, measurable, if at all, to the buyer's specifications. Improvements for the suppliers were seen by Company $\mathrm{C}$ managers as incidental, and for those individual firms to calculate and measure.

Without a framework for implementation and evaluation of outcomes, ORAs can become a blunt instrument. Even with a framework for use, it has been suggested that ORAs should have a specific contextual role in MRO or 'leverage' items (Smart and Harrison, 2002) which may not necessarily relate to wider supply chain goals. This case suggests that auctions are not being deployed as a genuinely integrative mechanism. Instead they are typically used by buyers as a means to extract value from the purchasing transaction.

\subsection{Company D - Cisco: Supply chain integration through a private exchange}

A supplier of hardware and software for the world wide web through products such as routers, switching technology, networks and supporting software, Cisco has been proffered as the leading firm in the world in achieving integration of data and processes across multiple levels in the supply chain (Kraemer and Dedrick, 2002). Cisco has created a virtual organisation through the linking of its supply chain partners utilising a complex network of platforms which enable almost all of its business transactions to take place over the web. At the time of this study Cisco's 'ecosystem' used two principal outward-facing platforms, integrated with its internal ERP system ${ }^{1}$.

The customer network (Cisco Connection Online: CCO) allows customers and resellers to place, configure and manage orders using automated ordering software. Users also have access to online technical assistance, a forum of technical experts and intelligent agents which support customer service. The supply side extranet (Manufacturing Connection Online: $\mathrm{MCO}$ ) is the resource for contract manufacturers, suppliers and logistics service providers, giving access to real-time order and fulfilment data. The community of vendors has direct access to order information allowing a swift and agile response to customer requirements. Wherever possible, a

\footnotetext{
${ }^{1}$ Since the research was undertaken, there have been developments in the Cisco system architecture.
} 
process, activity or function has been web-enabled ensuring a consistency of culture and performance within the business and to a large extent across the virtual organisation it supports. It was not feasible in the context of this study to gather data by which we could evaluate, for example in scales or quartiles, the advantages achieved by suppliers and customers using the Cisco online SCM mechanisms. However, all of those interviewed experienced significant operational benefits such as visibility on orders, fewer logistics failures, less dependence on variable forecasts, lower inventories and more reliability in processes.

The network created by Cisco illustrates how a private exchange (Whitaker et al., 2001) can be created to support the supply chain across multiple organisations. However it is important to note that there is a focal firm or 'prime mover' (Bagchi and Skjoett-Larsen, 2002) in this virtual enterprise which defines and manages the supply chain processes. Cisco works with members of the supply chain and assists them in adopting the web based systems in order to achieve operational parity. This case offers a rare example of a company which has created an integrated global supply chain through the deployment of web-based solutions across multiple tiers. Other firms have attempted to achieve this through public or consortia marketplaces (Laseter et al., 2001) but in most cases these failed to deliver due to a combination of technological or organizational issues (the much-heralded Covisint consortium in the automotive industry which closed in 2004 is an example). We suggest that the private exchange mechanism operated by Cisco is the most logical marketplace solution as it reflects the operational reality of a supply chain in today's global business environment. Equally it can be observed that the ecosystem only came into being as a result of the vision and execution capability of the driver of this supply chain. Cisco's business model as well as the products and the corporation itself are relatively new creations, unhindered by the baggage carried by most industrial firms. Most businesses operate in networks and contractual situations developed over decades or longer, as well as carrying assets and legacy IT systems which take time to substitute. For these firms, the barriers to integration are structural and cultural due to the difficulty of re-engineering the operational processes, both internally and externally.

The leading-edge supply chain solutions Cisco has implemented have been a key element in its success, allowing more focus on core growth activities. Equally, the ecosystem is not a democratic association of equals and it can be argued that Cisco 
has effectively leveraged its assets to achieve a position of power. Here, Cisco possesses the organisational flexibility, IT and employee competences and the dominant market status (vis-a-vis both customers and suppliers) to drive through a programme of innovation such as the ecosystem. In this case however, that power has been used to deliver value and benefits amongst the supply chain participants through the visibility created by integration of processes across the network.

\section{Findings and Discussion}

In the first three case studies we can observe commonalities in the impact of the eBusiness mechanisms deployed by companies A, B and C. Following the definitions in the Frohlich and Westbrook (2001) model we define their activities as lying within the lowest integration level, or as 'inward-facing' arcs of integration. Similarly, if we use the Bagchi and Skjoett-Larsen (2002) three-layer framework, in companies A, B and $C$, the stages of both information and organisational integration would be classified as 'low'. Indeed we suggest that the real level of integration, as defined by the constructs in these two frameworks, is practically non-existent. The companies are involved in the exchange of data electronically which leads to the automation of some processes, mainly within the narrow sales or purchase order cycle. However, as we have seen, this leads to no further definable benefits, measurable across the supply chain. There is a marked contrast in the Cisco case, where following Frohlich and Westbrook (2001) there is a strong 'outward-acing' arc of integration. Similarly, according to the Bagchi and SKjoett-Larsen (2002) definitions, Cisco provides a good example of 'high' levels of information and organizational integration (see Table 4).

Table 4: Levels of integration in the four case studies (from Figures 2 and 3)

\begin{tabular}{|l|l|l|}
\hline & $\begin{array}{l}\text { According to Frohlich \& } \\
\text { Westbrook model }\end{array}$ & $\begin{array}{l}\text { According to Bagchi \& } \\
\text { Skjoett-Larsen model }\end{array}$ \\
\hline Firm A & Inward-facing & Low \\
\hline Firm B & Inward-facing & Low \\
\hline Firm C & Inward-facing & Low \\
\hline Cisco & Outward-facing & High \\
\hline
\end{tabular}


To understand the very limited extent of integration in three of these cases, we need to examine the situational business reasons. Importantly, in the sell-side and buyside examples, it was apparent from our discussions with managers in all three organisations that the projects were based on an internal business case, designed to create value for the focal firms and to improve their specific processes and costs. $A$ limited benefits case was considered for the partners to the transaction, usually to support the argument for external adoption or deal with objections, but this was not a driver for the change in practice. In other words, the firms did not begin with a supply chain perspective. Indeed, the broader supply chain issues have barely been considered, in so far as the impact on the transactional partner's business is concerned. In these cases, the focal firms have sought to manage control of a key resource, either the buying or sales channel, in order to more efficiently manage orders with either their customers or suppliers.

The Cisco case is wholly different and illustrates that broader, external integration is achievable, in this instance in support of a virtual enterprise network. The case presented here supports the assertion by Bagchi and Skjoett-Larsen (2002: 104) that 'the success of a drive to integrate the supply chain depends on the power, influence, motivation and zeal of the prime mover in the supply chain'. The sophistication of the Cisco solution is unusual and has only been emulated by a handful of firms and as Akkermans et al. (1999) have suggested, innovative newcomers may be able to change the rules of SCM in an industry. Moreover, it raises an important question about how value is created and distributed in e-enabled supply chain networks. Cisco's ecosystem came about through the guiding hand of a powerful focal firm, yet benefits have accrued to the supply chain participants through sharing of demand data and more efficient management of inventories leading to minimisation of obsolescence and risk. Despite discussion of anticipated supply chain optimisation through marketplaces and exchanges (Kaplan and Sawhney, 2000; Laseter et al., 2001) the principal reason that most of them failed was the suppliers' concern that they would be unable to realise any benefits. This concern has proved a major obstacle to e-marketplace adoption and it is usually only where a mutually beneficial solution has been developed that the electronic marketplace has been a success. The marketplace or exchange model may itself be overtaken be newer technology solutions (de Burca et al., 2005; Themistecleous and Corbitt, 2006) such as Enterprise Application Integration (EAI). 
The new wave of eBusiness solutions did not appear in a linear progression, offering incremental improvements with one mechanism following the next. They appeared simultaneously over a short period and many early investors, for example in emarketplace solutions, were forced to write off major investment capital (Tonner, 2004). Some of the managers interviewed in this study suggested this experience has made firms more cautious with their investments and that a more selfish approach may have developed where they realise they can grasp benefits for themselves through eBusiness implementations. This attitude would suggest that the broader supply chain picture will be ignored. It should be recognised here that connecting functions between companies through IT solutions does not constitute integration. In reality what is achieved is often no more than automation of a transaction, with one side of the exchange benefiting over the other, according to the relative power positions occupied. In some cases, such as with buy-side eProcurement applications, the system may be imposed on suppliers who are threatened with withdrawal of business if they do not co-operate.

Van Hoek (2001: 21) has stated that 'very often virtual integration is applied in an operational manner and in segments of the supply chain only, as opposed to......strategic and integral supply chain involvement'. A more holistic approach will require an expanded, multi-company perspective amongst trading partners. Where IT projects are proposed and implemented by specific functional departments, we observed that usually those managers did not have access to data which would permit a broader supply chain business case. The starting point for this to be achieved, is for organisations to have integrated internal supply chain structures and Fawcett and Magnan (2002) demonstrate that this starting point is still yet to be reached in most businesses. For greater integration to develop (as defined in the frameworks referenced above), supply chain partners will need to share common mindsets and objectives, recognising the need to deploy mutually agreed processes, technologies and solutions to common problems. Whilst a number of articles amongst those in our literature review suggest that it is on the increase, our findings support the assertion of Bagchi and Skjoett-Larsen (2002) that external supply chain integration is generally uneven and usually absent. 


\section{Conclusions and lessons learnt}

The variety in the cases examined here allows us to draw conclusions on some key issues concerning the use of eBusiness or IT mechanisms in supply chain management.

Firstly, web sites or online sales catalogues established by sellers as a channel to market will have as objectives either supporting a market development or penetration strategy, or may be used as a defence mechanism against the imposition of eProcurement tools by large-scale purchasers. In effect they are not designed as supply chain solutions and cannot fulfil such a role unless they are integrated with both the seller's own ERP, or equivalent, systems and more importantly, those of the buying firms.

Secondly, whilst eProcurement applications have been widely adopted by the purchasing function, their impact on supply chain performance is not well understood. Where their use is solely or primarily driven by purchasing functional requirements the supply chain implications will be not measured. Indeed, our case reveals that the supply chain was never a consideration in the implementation and there was little or no understanding of the potential on-cost downstream. In order for there to be any possibility of an integrated solution being developed, such applications must be part of a supply chain level benefits analysis and not be driven purely by procurement functional targets.

Thirdly, online reverse auctions are premised on creating value for buyers through spend leverage and process improvements. We found no evidence of supply chain considerations in the implementation of reverse auctions technology, a finding supported by other studies on this topic. Whilst suppliers may realise some benefits either in process or cost reduction in response to tenders, there is effectively no supply chain level integration through this technology. This will only occur when firms move beyond pure cost-based metrics as a basis for implementation. As with eProcurement applications, we found that the business case was based on benefits delivered to the buying firm only.

Next, private (as opposed to public or vertical) exchanges are the most likely new eBusiness mechanism to facilitate supply chain integration. The Cisco ecosystem example illustrates how integration both upstream and downstream is achievable 
and similar outcomes may be delivered in future through the networking of firms' ERP systems. However the fundamental difference in the implementation of this infrastructure is the distribution of benefits to members of the supply chain, through real-time visibility and response, information sharing and reduced risk. This type of solution will often require one firm to initiate the infrastructure on which such interdependent systems and processes are established. Such an approach also permits the standardisation of data and processes, further facilitating measurement, reporting and error correction, which build levels of trust between the firms operating in this supply chain.

This paper has contributed to studies in the domain by illustrating that functional or silo-based thinking still drives current eBusiness implementation in supply chain contexts. Evidence from the case studies advances the literature in this area by demonstrating that the buy and sell-side applications discussed here will not lead to integrated supply chain solutions, unless they are approved within a structure of IT integration which supports supply chain level benefits analysis. This should be an issue of concern, as IT has often been proposed in the literature as the means to advance integration, not inhibit it. Further, it has been identified in these cases that buy and sell-side applications may create obstacles to further integration in the supply chain if they are used to achieve purely functional targets, or if the firm's trading partners are forced to adopt technologies which raise their respective operating costs. Hence frameworks which classify all such mechanisms as 'supply chain solutions' are misleading and they should be differentiated from genuine supply chain management mechanisms such as private exchanges, through which deeper levels of external process integration may be achieved. Equally, this step will require the influence of a focal firm, which recognises the potential for supply chain benefits through such integration and it is often the absence of such a prime mover which inhibits success. This paper proposes that firms which seek to integrate externally in order to deliver supply chain cost and service improvements, in which suppliers and/or customers participate, should use lessons from the private exchange or ecosystem model to develop appropriate supply chain-level IT strategies. 


\section{Further research}

One can only make limited generalisations from a small number of case studies, as presented here, and to ascertain a more global perspective of the impact of these eBusiness mechanisms will require further in-depth studies and perhaps a surveybased approach. This subject area is in itself problematic in that authors offer alternative or contradictory interpretations of 'supply chain integration'. The published frameworks referenced in this article use different constructs and activities in defining both supply chain integration and the levels which pertain within it. Research which seeks to formalise our understanding of the components of integration (which in practice may vary between industry sectors) will assist the debate considerably. Further studies in this domain should therefore seek to explore the impact of eBusiness adoption in a wider sample of companies and to establish a typology of attributes which should form the basis for successful supply chain integration.

\section{References}

Akkermans, H., Bogerd, P. and Vos, B. (1999), "Virtuous and vicious cycles on the road to international supply chain management", International Journal of Operations \& Production Management, 19, pp. 565-581.

Barratt, M. and Oliveira, A. (2001), "Exploring the experiences of collaborative planning initiatives", International Journal of Physical Distribution and Logistics Management, 31, pp. 266-289.

Bagchi, P., \& Skjoett-Larsen, T. (2002), "Integration of Information Technology and Organizations in a Supply Chain", The International Journal of Logistics Management, Vol.14, No. 1, pp. 89-108.

Bowersox, D., Closs, D. and Stank, T. (2003), "How to Master Cross-Enterprise Collaboration", Supply Chain Management Review, July-August, pp. 18-27.

Cagliano, R., Caniato, F. and Spina G. (2003), "E-business strategy: How companies are shaping their supply chain through the Internet", International Journal of Operations and Production Management, Vol. 23, No. 10, pp. 1142-1162. 